\title{
EVOLUTION IN SMALL POPULATIONS: EVIDENCE FROM THE LITERATURE AND EXPERIMENTAL RESULTS
}

\author{
RAYMOMD L. TREMBLAY ${ }^{1,2,3} \&$ JAMES D. ACKERMAN ${ }^{2}$ \\ ${ }^{1}$ Department of Biology, 100 Carr. 908, University of Puerto Rico - Humacao campus, Humacao \\ Puerto Rico, 00791-4300, USA \\ ${ }^{2}$ Department of Biology, PO Box 23360, University of Puerto Rico - Rio Piedras campus, San Juan \\ Puerto Rico, 00931-3360 \\ ${ }^{3}$ Author for correspondence: raymond@hpcf.upr.edu
}

The great taxonomic diversity of the Orchidaceae is often attributed to adaptive radiation for specific pollinators driven by selection for outcrossing. However, when one looks beyond the product to the process, the evidence for selection is less than overwhelming. Here we review a number of investigations that attempted to determine if natural selection is present in a variety of orchids based on the data from the literature in addition to our own research to understand the relative importance of this process. We illustrate through these examples that attempts to measure and demonstrate evidence for natural selection reveal selection coefficients that are most often small and non-significant. From the literature we show selection studies for morphological variation in Lepanthes rupestris Stimson (Cintrón-Berdecia \& Tremblay 2006), unpublished work on selection coefficients for color variation in Lepanthes rupestris (Tremblay \& Ackerman, submitted), color variation in Bletia patula Graham (Ackerman \& Carromero 2005) and in Psychilis monensis Sauleda (Aragon and Ackerman 2004), and phenotypic selection for size in Caladenia gracilis $\mathrm{R}$. Br.

Prior to any studies evaluating the potential for evolution, it is important to determine that the characteristics of interest are heritable. Genetic variation is not the only cause of morphological variation. Morphological variation can be a result of the environmental factors and also by the interaction between genetics and environmental (G X E, phenotypic plasticity). In the studies that follow we assume that most morphological variation is a direct result of genetic variation or genetic by environment interaction and not dominated by environment. Previous results suggest that significant variation attributable to environment can occur in some floral characteristics but others appear relatively unaffected by environmental changes (Morales Vargas 2003).

\section{Size: Is it superficial?}

In the first example Cintrón-Berdecia and Tremblay (2006) sought to identify floral characters that suggested evidence for either linear, disruptive or stabilizing selection on flowers of more then 200 individuals of Lepanthes rupestris Stimson in seven populations along two river systems. None of the analyses suggested that any of the characters were under selection in all populations. They found scattered evidence that some of the characters had positive reproductive output through either pollinaria removal or fruit set when the floral character was larger (length of column; in two populations; mid lobe length, lip width, posterior petal lobe), while other characters suggested negative effect when characters were larger (width of anterior petal lobe, front lip length, flower size). A few characters appear to be subjected to disruptive selection (length of anterior petal lobe, width of anterior petal lobe, front lip width) and stabilizing selection (length posterior petal lobe, distance between sepals, Table 1). In spite of this the most outstanding result of the survey is the complete inconsistency in significant selection coefficients in any of the characters among populations. The character with the most frequent significant selection coefficient was the length of the column, which was found only in two populations, through both pollinaria removal and fruit set.

When all data from the seven populations are summed and analyzed, the length of the column is again the only character where the linear selection coefficient is significantly different using both measure of reproductive success (larger column length have higher selection coefficient on reproductive success, $6.2 \%$ (pollinaria removal) and $5.3 \%$ (fruit set). The length of the lip and distance between sepals were also found to be positively correlated with size through pollinaria removal. 
TABLE 1: Univariate $\left(s^{\prime}, \beta^{\prime \prime}\right)$ and multivariate $\left(\gamma^{\prime}\right)$ selection acting through female success (fruit set) fitness on 12 characteristics in one populations of Lepanthes rupestris and the sum of all seven populations (populations 2 to 7 not shown; see Cintrón - Berdecia and Tremblay 2006). Standardized selection coefficients are represented as directional $\left(s^{\prime}, \beta^{\prime}\right)$ and non-lineal $\left(\gamma^{\prime}\right.$, negative values $=$ stabilizing selection, positive values $=$ disruptive selection $)$ and given in units of phenotypic standard deviation. Bold numbers are significant at the following levels, ${ }^{*} \mathrm{P} £ 0.05,{ }^{* *} \mathrm{P} £ 0$.

\begin{tabular}{|c|c|c|c|c|c|c|c|c|}
\hline \multirow{2}{*}{$\begin{array}{c}\text { Female Fitness } \\
\text { Traits }\end{array}$} & \multicolumn{4}{|c|}{ Population 1} & \multicolumn{4}{|c|}{ All Populations } \\
\hline & $\mathrm{n}$ & $s^{\prime}$ & $\beta$, & $\gamma^{\prime}$ & $\mathrm{n}$ & $s^{\prime}$ & $\beta^{\prime}$ & $\gamma^{\prime}$ \\
\hline Length of Column & 35 & $.189 *$ & .200 & .054 & 201 & $.062 * *$ & .048 & .001 \\
\hline Width Sepal Dorsal & 29 & .163 & .058 & -.054 & 189 & .022 & -.018 & -.001 \\
\hline Length Posterior Petal Lobe & 29 & .113 & -.066 & -.141 & 187 & .018 & .002 & -.001 \\
\hline Width Posterior Petal Lobe & 29 & .086 & .032 & -.077 & 188 & .029 & .032 & -.018 \\
\hline Length Anterior Petal Lobe & 29 & .131 & .043 & -.123 & 189 & .044 & -.040 & -.001 \\
\hline Width Anterior Petal Lobe & 29 & .218 & .122 & -.003 & 189 & .010 & .058 & .003 \\
\hline Front Lip Length & 29 & .077 & .061 & -.044 & 186 & $.052 * *$ & .043 & -.003 \\
\hline Front Lip Width & 29 & $.439 *$ & .182 & .036 & 186 & .012 & .009 & .011 \\
\hline Mid Lobe Length & 26 & -.033 & -.200 & .032 & 176 & .023 & .023 & -.002 \\
\hline Anther Cap Open & 28 & -.068 & -.204 & .043 & 184 & .016 & -.092 & .011 \\
\hline Distance Between Sepals & 27 & .040 & .058 & .008 & 184 & $.017^{*}$ & .007 & 011 \\
\hline Flower Size & 33 & .090 & .170 & -.158 & 208 & .010 & -.004 & .008 \\
\hline
\end{tabular}

However, fruit set suggests that the distance between sepals was under disruptive selection (Table 1).

\section{Color: Can you see it and do you care?}

In the second example Tremblay and Ackerman (unpublished) sought to measure phenotypic selection on petal color variation in populations of Lepanthes rupestris. Plants have flowers with either unicolor or bicolored petals. The two color morphs are otherwise inseparable morphologically. Reproductive success is skewed towards few individuals and effective population sizes are estimated to be small. We censused seven populations monthly for 20 months or more and noted flower production and petal color pattern. Each flower was checked for pollinarium removal (a measure of male fitness) and fruit production (a measure of female fitness). In all populations, plants with bicolored petals dominated, comprising $63-82 \%$ of individuals. Nevertheless the two types were indistinguishable based on reproductive success. Flower color pattern was generally not associated with either male or female reproductive success within or among populations or over time. Although we were unable to tag fitness to petal color patterns, the consistent ratio of color morphs among populations suggests that factors other then just drift are responsible for the frequencies we observed within a population.

In food-deceptive orchids, variation in floral characteristics associated with pollinator attraction is expected to be high, largely due to either relaxed selection or negative frequency-dependent selection (Ackerman \& GalarzaPérez 1991). Relaxed selection would occur if flower color made no difference, as may be the case for Lepanthes rupestris. Negative frequency dependent selection occurs when being different imparts an advantage because pollinators will more quickly learn that similar phenotypes have no rewards. Ackerman and Carromero (2005) surveyed populations of Bletia patula in the Dominican Republic in a region where two color morphs were common: pink flowered and white flowered plants. While no morphological differences between the two color morphs were detected, there were differences in reproductive success between the two. The white-flowered plants had an advantage through male function (they were more likely to have pollinaria removed than pinkflowered plants). However, success was not related to color morph frequencies, neither negatively nor positively. The two color morphs also occur in Puerto Rico, but the white-flowered plants are extremely rare precluding any comparison between populations of the two islands. 
When color variation is bimodal, such as in Lepanthes rupestris and Bletia patula, it is relatively easy to associate a color morph with pollinator behavior and reproductive success. However, in most orchids with substantial variation in floral color the variation is continuous. Under such circumstances it is somewhat more difficult to interpret variation in pollinator behavior and plant reproductive success. In an experimental study Aragón and Ackerman (2004) manipulated color variation in Psychilis monensis, creating uniformly and variably colored populations. As plants of this species flower all year, treatments were rotated among populations over time. They found that over $50 \%$ of the variation in either male or female reproductive success was explained by time and site with no significant effect of treatment except as part of a three-way interaction of time X site $\mathrm{X}$ treatment. Population variation in floral color had little or no effect on reproductive success. Major community changes had occurred during the experiment with flowering activity of sympatric species falling dramatically and by the third run of the experiment, only $P$. monensis was in flower. This is when the number of effective visits significantly increased. They concluded that high natural levels of color variation may be more influenced by drift than selection

\section{Showing off: Size matters}

Selection may also act on floral display and thus there is an opportunity for pollinator-mediated selection (Williams \& Conner 2001, Kobayashi et al. 1997, Worley et al. 2000, Totland et al. 1998). Caladenia (Stegostyla) gracilis R. Br. is a widespread terrestrial orchid from Eastern Australia. Tremblay (2006) surveyed populations at two sites in the state of Victoria.

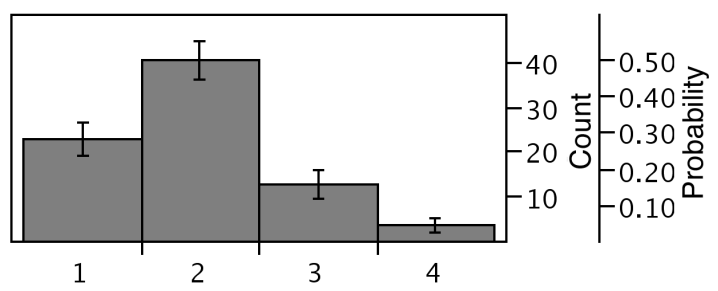

FIGURE 1: Frequency (s.e.) distribution of floral display size in 81 individuals of Caladenia gracilis at two sites in the state of Victoria, Australia.

Inflorescences have 1-6 flowers, each about $30 \mathrm{~mm}$ across (Tremblay 2005). A total 81 plants at two sites were sampled for reproductive success (pollinaria removed, pollination and fruit set) as a function of number of flowers on a plant. Plants with two flowers was the most common display size at both sites (mean + s.e.; $2.0 \pm 0.11$; Figure 1).

Plants that have fewer flowers have a very low probability of having their pollinaria removed or deposited or setting fruit. The probability of reproductive potential was significantly higher in multi-flowered individuals (Logistic regression; log likelihood $=$ 8.134, df 1, 80, $\mathrm{p}<0.0001$ : Table 2).

A literature review of some of the evidence of the effect of floral display on reproductive success in orchids suggests that when significant effects occur, reproductive success is higher in larger inflorescences, although it does not necessarily increase proportionately with an increase in the number of flowers (Montalvo \& Ackerman 1987). However, in a number of orchid species pollinators appear to have no preference for floral display size (Table 3). The ability to detect a significant effect is sample size dependent, however there is no evidence to suggest that these non-significant results are an aberration. Moreover, the effect of reproductive success on floral display can be

TABLE 2. The expected male and female reproductive success of individuals of Caladenia gracilis with varying floral display. Analysis of receiver operating characteristics (ROC) calculates the most likely state of each of the type of floral display from the logistic regression equation. Thus a flower on a two-flowered inflorescence has a $32 \%$ chance of having the pollinaria removed, while on a four-flowered inflorescence, an individual flower has an $89 \%$ chance of having the pollinaria removed.

\begin{tabular}{c|c|c|c}
$\begin{array}{c}\text { Floral display } \\
\text { (number of flowers) }\end{array}$ & $\begin{array}{c}\text { Expected percent pollinaria } \\
\text { removal }\end{array}$ & $\begin{array}{c}\text { Expected percent pollinaria } \\
\text { deposition }\end{array}$ & $\begin{array}{c}\text { Expected percent } \\
\text { Fruit set }\end{array}$ \\
\hline 1 & 0.11 & 0.09 & 0.10 \\
\hline 2 & 0.32 & 0.17 & 0.21 \\
\hline 3 & 0.66 & 0.30 & 0.37 \\
\hline 4 & 0.89 & 0.47 & 0.57 \\
\hline
\end{tabular}


inconsistent among time and space, as it has been shown for other characters (Maad 2000, Ehlers et al. 2002; Tremblay \& Ackerman, unpublished).

Among the different studies discussed above, no general pattern of selection was observed for color morphs or morphological characters. The selective advantage of floral color could be affected by a number of variables, the first is it assumes that the pollinators can visualize the color variation perceived by humans, secondly it assumes that the color variation is sufficiently discrete so they care enough to make a choice between the variants. Furthermore, the ecological context may make all the difference as well. Some European, rewardless orchids have dramatic flower color polymorphisms as in Bletia patula, but unlike the tropical species, color and its frequency have been shown to make a difference to orchid reproductive success (Smithson \& Macnair 1997, Gigord et al. 2001). Such differences in response to color poly-

TABLE 3: Effect of floral display on reproductive success in orchids. "+" = positive effect of larger floral display on reproductive success, "-" = negative effect of larger floral display on reproductive success, "D" = disruptive selection, NS $=$ no significant effect of floral display on reproductive success.

\begin{tabular}{|c|c|c|c|c|}
\hline Species & $\begin{array}{l}\text { Variation in } \\
\text { number of flowers }\end{array}$ & $\begin{array}{c}\text { Pollinaria } \\
\text { removal }\end{array}$ & Fruit set & References \\
\hline Aspasia principissa Rchb. f. & $1-7$ & + & + & Zimmerman \& Aide 1989 \\
\hline Brassavola nodosa (L.) Lindl. & $1-5$ & + & + & Schemske 1980; Murren \& Ellisson 1996 \\
\hline $\begin{array}{l}\text { Calopogon tuberosus (L.) Britton, } \\
\text { Sterns \& Poggenb. }\end{array}$ & $1-10$ & & NS & Firmage and Cole 1988 \\
\hline Comparettia falcata Poepp. \& Endl. & $1-9$ & + & + & Rodríguez et al. 1992 \\
\hline $\begin{array}{l}\text { Cyclopogon cranichoides (Griseb.) } \\
\text { Schltr. }\end{array}$ & $8->40$ & & + & Calvo 1990 \\
\hline Dactylorhiza maculata (L.) Soó & Mean 15 & & NS & Vallius 2000 \\
\hline $\begin{array}{l}\text { Elythranthera brunonis (Endl.) A.S. } \\
\text { George }\end{array}$ & & NS & NS & Tremblay et al. this issue \\
\hline Psychilis krugii (Bello) Sauleda & $1-8$ & NS & NS & Ackerman 1989 \\
\hline Epidendrum exasperatum Rchb. f. & $6-358$ & + & & Calvo 1990 \\
\hline Epipactis helleborine (L.) Crantz & $\begin{array}{l}\text { 15-30? data absent } \\
\text { from paper }\end{array}$ & + & + & Ehlers, et al. 2002,Piper and Waite 1988 \\
\hline Gastrodia exilis Hook. f. & $2-13$ & & NS & Pedersen et al. 2004 \\
\hline Ionopsis utricularioides (Sw.) Lindl. & $1-44$ & + & $+(-)^{*}$ & Montalvo \& Ackerman, 1987 \\
\hline Lepanthes wendlandii Rchb. f. & $1-123$ & & NS & Calvo 1990 \\
\hline Malaxis massonii (Ridl.) Kuntze & $6-106$ & + & + year dependent & Aragón \& Ackerman 2001 \\
\hline $\begin{array}{l}\text { Oeceoclades maculata (Lindl.) } \\
\text { Lindl. }\end{array}$ & $4-16$ & & NS & Calvo 1990 \\
\hline Orchis purpurea Huds. & $9-98$ & & NS & Jacquemyn et al. 2002 \\
\hline Platanthera bifolia (L.) Rich. & $10-20$ & + & + & Maad 2000 \\
\hline $\begin{array}{c}\text { Oligochaetochilus (Pterostylis) } \\
\text { longifolia (R. Br.) Szlach. }\end{array}$ & $\begin{array}{l}\text { 1-5 data absent from } \\
\text { paper }\end{array}$ & NS & NS & Hamilton 2003 \\
\hline $\begin{array}{l}\text { Rhyncholaelia glauca (Lindl.) } \\
\text { Schltr. }\end{array}$ & $1-17$ & NS & NS & Flores-Palacios \& Garcia-Franco 2003 \\
\hline Tolumnia variegata (Sw.) Braem & $1-15$ & & $\mathrm{D}$ & Sabat \& Ackerman 1996 \\
\hline
\end{tabular}

* Large inflorescences produce more fruits than small inflorescences, but for those plants that produce fruit, there is a strong negative relationship between fruit number and flower number. 
morphisms among species with similar pollination strategies suggests that other factors are at play.

However consistency in selection of larger inflorescence appears to be common. Selection on floral display size and reproductive successes clearly shows that larger inflorescences size appears to offer an advantage. However, the observed advantage may not be easily explained. Tremblay (2006) showed that larger display sizes are advantageous in Caladenia gracilis, which was not expected, as this species belongs to a mostly single flowered clade of the Caladeniinae. If this evolutionary advantage has been present prior to the study, then why are larger inflorescences not more common in this clade? Constraints to display size and its evolution must be present and could be influenced by complex heritability, inbreeding depression, costs to reproduction and phenotypic plasticity. Behavioral differences among pollinators of the different species may also play a role as would the ecological context in which the orchid populations exist. To evaluate the potential for natural selection on floral display a number of parameters need to be evaluated. Do flowering individuals come back with the same number of flowers (at least in the same range) as previous flowering events? Is the lifetime reproductive success of a large individual equal to small individuals? What is the importance of phenotypic plasticity on floral display? At present those data are generally missing from the literature for terrestrial and epiphytic orchids.

We found no evidence in the orchid literature on the frequency of individuals expressing a specific floral display size among flowering period. Determining if that display size is genetically influenced, however a substantial amount of evidence suggests that there is a cost to reproduction in many species of orchids which often results in reduce display size in the next reproductive bout or emerging as vegetative individual or not at all (dormant) (Pfeifer et al. 2006, Coates et al. 2006 Tremblay et al. 2005). Consequently display size may be very plastic and not a good character for predicting selection coefficients. Short surveys maybe inconsequential to evolutionary processes. It may be more appropriate to evaluate this character considering the lifetime reproductive success of the individuals and a measure of mean display size throughout that lifespan.

Gentry and Dodson (1987) have suggested that evolutionary processes in orchids can be quick and that within a few generations cladogenesis can occur. Under a basic Darwinian evolutionary process selection coefficients would then have to be high and consistent among time periods for evolution to be quick. Others contend that such processes may be slow (Soto-Arenas
1996) and there is some genetic evidence for it (Corrias et al. 1991, Rossi et al. 1992, Ackerman \& Ward 1999). A third possibility is that in many situations, genetic drift may be equally important as natural selection in fostering genetic and morphological variation in this family (Tremblay et al. 2005). We favor this vision and suggest that the great diversity in this family to be largely a consequence of sequential and rapid interplay between drift and natural selection.

\section{LITERATURE CITED}

Ackerman J. D. \& W. Carromero. 2005. Is reproductive success related to color polymorphism in a deceptionpollinated, tropical terrestrial orchid? Caribbean J. Sci. 41: 234-242.

Ackerman, J. D. \& S. Ward. 1999. Genetic variation in a widespread, epiphytic orchid: where is the evolutionary potential? Syst. Bot. 24: 282-291.

Aragón, S. \& J. D. Ackerman. 2001. Density effects on the reproductive success and herbivory of Malaxis massonii. Lindleyana 16: 3-12.

Calvo, R.N. 1990. Four-year growth and reproduction of Cyclopogon cranichoides (Orchidaceae) in South Florida. Amer. J. Bot. 77: 736-741.

Cintrón-Berdecía S.-T. \& R. L. Tremblay. 2006. Spatial variation in phenotypic selection on floral characteristics in an epiphytic orchid. Folia GeoBot. 41: 33-46.

Coates, F., I. Lunt \& R. L. Tremblay. 2006. The effect of fire, rainfall, herbivory on population dynamics of a threatened terrestrial orchid from south-eastern Australia, Prasophyllum correctum D.L. and consequences for management. Biol. Conserv. 129: 59-69.

Corrias, B., W. Rossi, P. Arduino, R. Cianchi \& L. Bullini. 1991. Orchis longicornu Poiret in Saardinia: genetic, morphological and chorological data. Webbia 45: 71-101.

Ehlers, B.K., J.M. Olesen \& J. Agren. 2002. Floral morphology and reproductive success in the orchid Epipactis helleborine: regional and local across-habitat variation. Pl. Syst. Evol. 236: 19-32.

Firmage, D.H. \& F.R. Cole. 1988. Reproductive success and inflorescence size of Calopogon tuberosus (Orchidaceae). Amer. J. Bot. 75: 1371-1377.

Flores-Palacios, A. \& J.G. Garcia-Franco. 2003. Effects of floral display and plant abundance on fruit production of Ryncholaelia glauca (Orchidaceae). Rev. Biol. Trop. 51: 71-78.

Gentry, A. L. \& C.H. Dodson. 1987. Diversity and biogeography of neotropical vascular epiphytes. Ann. Missouri Bot. Gard. 74: 205-233.

Gigord, L. D. C., M. Macnair \& A. Smithson. 2001. Negative frequency-dependent selection maintains a dramatic flower color polymorphism in the rewardless orchid Dactylorhiza sambucina (L.) Soó. Proc. Natl. Acad. Sci. USA 98: 6253-6255. 
Hamilton, J. 2003. Towards an understanding of pollination in the Australian Terrestrial orchid Pterostylis longifolia (Brown). Honours thesis, The Australian National university, Camberra, Asutralia.

Jacquemyn, H., R. Brys \& M. Herny. 2002. Flower and fruit production in small populations of Orchid purpurea and implications for management. Pp. 67-84 in: P. Kindlmann, J. H. Willems and D. F. Whigham (eds.). Trends and fluctuations and underlying mechanisms in terrestrial orchid populations.

Kobayashi, S., K. Inoue \& M. Kato. 1997. Evidence of pollen transfer efficiency as the natural selection factor favoring a large corolla of Campanula punctata pollinated by Bombus diversus. Oecologia 111: 535-542.

Maad, J. 2000. Phenotypic selection in hawkmoth-pollinated Platanthera bifolia: Targets and fitness surfaces. Evolution 54: 112-123.

Morales Vargas, M. 2003. Variation and reproductive success across light environments in the common epiphytic orchid, Tolumnia variegata (Orchidaceae). M.S. Thesis, University of Puerto Rico, Río Piedras.

Montalvo, A.M. \& J.D. Ackerman. 1987. Limitations to fruit production in Ionopsis utricularioides. Biotropica 19: $24-31$

Murren, C.J. \& A.M. Ellison. 1996. Effects of habitat, plant size, and floral display on male and female reproductive success of the neotropical orchid Brassavola nodosa. Biotropica 28: 30-41.

Pedersen, H. A., S. Watthana, S. Suddee \& S. Sasirat. 2004. Nat. Hit. Bull. Siam Soc. 52: 9-26.

Pfeifer, M., W. Heinrich \& G. Jetschke. 2006. Climate, size and flowering history determine flowering pattern of Himantoglossum hircinum. Bot. J. Linnean Soc. 151:511-526.

Piper, J. G. \& S. Waite. 1988. The gender role of flowers of broad leaved Epipactis helleborine (L.) Crantz (Orchidaceae). Funct. Ecol. 2:35-40.

Rossi, W., B. Corrias, P. Arduino, R. Cianchi \& L. Bullini. 1992. Gene variation and gene flow in Orchis morio (Orchidaceae) from Italy. Pl. Syst. Evol 179: 43-58.
Sabat, A. M. \& J. D. Ackerman 1996. Fruit set in a deceptive orchid: The effect of flowering phenology, display size, and local floral abundance. Amer. J. Bot. 83: 11811186.

Schemske, D.W. 1980. Evolution of floral display in the orchid Brassavola nodosa. Evolution 34: 489-493.

Smithson, A. \& M. R. Macnair. 1997. Negative frequencydependent selection by pollinators on artificial flowers without rewards. Evolution 51: 715-723.

Totland, O., H.L. Andersen, T. Bjelland, V. Dahl, W. Eide, S. Houge, T.R. Pedersen \& E.U. Vie. 1998. Variation in pollen limitation among plants and phenotypic selection on floral traits in an early-spring flowering herb. Oikos 82: 491-501.

Tremblay, R. L. 2005. Larger is better: The effect of floral display on reproductive success in two populations of Caladenia (Stegostyla) gracilis R. Br. Muelleria 22: 77-85.

Tremblay, R. L,. J. D. Ackerman, J. K. Zimmerman \& R. Calvo. 2005. Variation in Sexual reproduction in orchids and its evolutionary consequences: A spasmodic journey to diversification. Biol. J. Linnean Soc. 84: 1-54.

Tremblay, R. L., R. M. Bateman, A. Brown, M. Hachadourian, M. J. Hutchings, S. Kell, H. Koopowitz, C. Lehnebach \& D. Whigham S Submitted. Density induced rates of pollinaria removal and deposition in the Purple Enamel-Orchid (Elythranthera brunonis). Lankesteriana, this issue.

Vallius, E. 2000. Position-dependent reproductive success of flowers in Dactylorhiza maculata (Orchidaceae). Func. Ecol. 14: 573-579.

Williams, J.L. \& J.K. Conner. 2001. Sources of phenotypic variation in floral traits in wild radish, Raphanus raphanistrum (Brassicaceae). Amer. J. Bot. 88: 1577-1581.

Worley, A.C., A.M. Baker, J.D. Thompson \& S.C.H. Barrett. 2000. Floral display in Narcissus: Variation in flower size and number at the species, population, and individual levels. Intern. J. Pl. Sc. 161: 69-79.

Zimmerman, J.K. \& T.M. Aide. 1989. Patterns of fruit production in a neotropical orchid: pollinator vs. resource limitation. Amer. J. Bot. 76: 67-73.

Raymond L. Tremblay is Professor of the University of Puerto Rico at Humacao and Rio Piedras Campuses. He is an evolutionary ecologist interested in the large question of why are there so many orchids. His present interests include studies in Population Viability Analysis of endangered species and in situ conservation of orchids.

James D. Ackerman is Professor of the University of Puerto Rico at Río Piedras. He is a biologist with broad interests, but focuses on the ecology, systematics and evolution of Orchidaceae. His present interests include studies on the relationship between land use history and orchid distributions, orchid biogeography, invasive orchids, and their mycorrhizal relationships. 